\title{
Resistance of tomato plant genotypes with high foliar allelochemical contents to the leafminer Liriomyza trifolii
}

\section{Resistência de genótipos de tomateiro com altos teores de aleloquímicos nas folhas à mosca-minadora Liriomyza trifolii}

\author{
Alex Antônio da Silva ${ }^{1 *}$, Marcela Carvalho Andrade', Wilson Roberto Maluf ${ }^{2}$, \\ Jair Campos Moraes ${ }^{3}$, Jéssica Figueiredo Rezende ${ }^{1}$
}

|||||||||||||||||||||||||||||||||||||||||||||||||||||||||||||||||||||||||||||||||||||||||||||||||||||||||||||||||||||||||||||||||||||||||||||||||||||||||||||||||||||||||||||||||||||||||||||||||||||||||||||||||||||||||||||||||||||||||||||||||||

\begin{abstract}
The objective of this study was to assess the resistance of tomato genotypes with high foliar levels of allelochemicals to the leafminer Liriomyza trifolii. Eight tomato genotypes with contrasting levels of three different alellochemicals were tested for leafminer resistance: the TOM-687 and TOM-688 lines, which are both rich in acylsugar; ZGB-703 and ZGB-704, which are rich in zingiberene; BPX-365G-899-07-04-02 and BPX-367E-238-02, which are rich in 2-tridecanone; and 2 standard commercial hybrids (Deborah Max and Bravo $\mathrm{F}_{1}$ ) with low-allelochemical content. Thirty days after being transplanted, nine potted plants of each of the treatments were transferred to a phytotron chamber, into which 1600 unsexed leafminer adults from a mass rearing were released. The number of mines and the percentage of leaves and leaflets attacked (= with the presence of punctures) were evaluated. Six days later, the number of pupae was recorded. The genotypes with high levels of acylsugar were associated with higher levels of resistance to leaf miner $L$. trifolii, through antixenosis and antibiosis mechanisms. At least one of the 2-tridecanone-rich lines (BPX -365G-899-07-04-02) showed some level of resistance via an antibiosis mechanism.
\end{abstract}

KEYWORDS: Insecta; Solanum lycopersicum; plant breeding; allomones.
RESUMO: Objetivou-se, neste trabalho, avaliar a possível resistência de genótipos de tomateiro com altos teores de aleloquímicos nas folhas, à mosca-minadora Liriomyza trifolii. Para tanto, foi montado um ensaio em delineamento inteiramente casualizado com oito tratamentos: linhagens TOM-687 e TOM-688, ricas em acilaçúcares; ZGB-703 e ZGB-704, ricas em zingibereno; BPX365G-899-07-04-02 e BPX-367E-238-02, ricas em 2-tridecanona; 2 híbridos comerciais, Débora Max e Bravo (testemunhas) e nove repetiçôes. Aproximadamente 30 dias após o transplante, vasos com uma planta correspondente a cada tratamento foram transferidos para uma câmara climatizada do tipo Fitotron, na qual foram liberados 1.600 adultos da mosca minadora, não sexados, oriundos da criação de manutenção. Avaliaram-se o número de minas, a porcentagem de folhas e folíolos atacados (com a presença de puncturas), e seis dias depois, contou-se o número de pupas. Os genótipos com altos teores de acilaçúcares mostraram-se associados a maiores níveis de resistência à mosca-minadora L. trifolii, tanto pelo mecanismo de antixenose como antibiose. Pelo menos uma das linhagens ricas em 2-tridecanona mostrou algum nível de resistência pelo mecanismo de antibiose.

PALAVRAS-CHAVE: Insecta; Solanum lycopersicum; melhoramento genético; alomônios. 


\section{INTRODUCTION}

Tomato Solanum lycopersicum L. is one of the most widely cultivated vegetables in the world, and is regarded as one of the crops most susceptible to attacks from phytopathogens and insect pests (CARVALHO et al., 2012). Among the insects that attack the crop and cause economic loss is the American serpentine leafminer Liriomyza trifolli (Burgess) (Diptera: Agromyzidae) (GALLO et al., 2002).

L. trifolii is found throughout the world and it causes direct and indirect damage to crops. The adult females of this species make punctures into the plant leaves with their sclerotized ovipositors in order to feed on the extravased cellular contents and insert eggs into the leaf mesophyll. This, in turn, results in the deformation of the leaves, especially at the apex and along the margins. From these eggs, larvae hatch that, while feeding, make meandering mines within the leaflets of the tomato plant. Each mine causes a loss of approximately $2 \%$ of the leaflet area (ERB et al., 1993). Estimates show that $18 \%$ of the area with mines results in a $60 \%$ loss in the photosynthesis rate of the leaflet, which is the most harmful direct damage. Indirect damage arises from puncture invasions made by plant pathogens such as the fungus Alternaria solani, which causes a disease known as early blight in the tomato plant (FORNAZIER et al., 2010).

Chemical sprays are the most often deployed methods of control, in spite of the fact that improper use of insecticides may not only cause environmental pollution and intoxication of farm workers, but may also leave residue on fruit and raise crop production costs (SILVA et al., 2009).

Sources of resistance to insects were identified in some species of the Solanum genus, Lycopersicon group, and were related to the domesticated tomato plant species. These resistances are largely attributable to the production of allelochemicals, which in some cases are present in leaf trichomes. Prominent among the species with such resistance are $S$. pennelii, which produces acylsugars (RESENDE et al., 2002; RESENDE et al., 2006), S. habrochaites var. hirsutum, which produces sesquiterpenes, such as zingiberene (FREITAS et al., 2002; MALUF et al., 2001; NEIVA et al., 2013), and also the specie $S$. harbrochaites var. glabratum, which produces a methyl-ketone, 2-tridecanone (GONÇALVES et al., 1998; OLIVEIRA et al., 2012).

The use of cultivars that are resistant to insects as part of an integrated pest management plan is considered to be an ideal control method because they are a non-pollutant, they are compatible with other control methods, they do not not interfere with other farming activities, and they do not impose an additional burden to production costs. Since the early 1990's, breeding programs in Brazil have developed tomato lines with high levels of foliar acylsugars, zingiberene and/ or 2-tridecanone. These lines have been demonstrated to be resistant to the whiteflies Bemisia spp. (MALUF et al., 2010; NEIVA et al., 2013), the South American tomato pinworm Tuta absoluta (AZEVEDO et al., 2003; GONÇALVES NETO et al., 2010; OLIVEIRA et al., 2012), spider mites Tetranychus spp. (MALUF et al., 2007), and to the aphid Myzus persicae (SILVA et al., 2013). The resistance of these genotypes to $L$. trifolii has not, however, been tested.

This study was therefore conducted to assess the resistance levels of tomato genotypes with contrasting foliar substances containing different allelochemicals (acylsugars, zingiberene or 2-tridecanone) to the leafminer $L$. trifolii.

\section{MATERIALS AND METHODS}

\section{Evaluation of tomato plant genotypes}

The plant genotypes being tested were comprised of six tomato lines (TOM-687, TOM-688, ZGB-703, ZGB-704, BPX365G-899-07-04-02, BPX-367E-238-02) with contrasting allelochemical contents. Two commercial hybrids were used as controls. The genotypes 'TOM-687' and 'TOM-688' are improved tomato inbred lines with high foliar acylsugar content. They were obtained from the original interspecific cross of S. lycopersicum x S. pennellii 'LA-716', followed by three backcrosses with $S$. lycopersicum, and were selected based on the high content of acylsugars in their leaflets (RESENDE et al., 2009), according to the methodology proposed by RESENDE et al. (2002). The genotypes 'ZGB703 ' and 'ZGB-704' are lines that possess high zingiberene content. They were obtained from the original interspecific cross of S. lycopersicum $\times$ S. habrochaites var. hirsutum 'PI127826', followed by two backcrosses of $S$. lycopersicum, with selection for a high foliar content of that sesquiterpene (AZEVEDO et al., 2003; FREITAS et al., 2012; MALUF et al., 2001). The genotypes 'BPX-365G-899-07-04-02' and 'BPX-367E-238-02' are lines with a presumably high content of the allelochemical 2-tridecanone (2-TD), and were selected due to their high density of glandular trichomes (MALUF et al., 2007) from a cross which involved a high2-TD line obtained from the interspecific cross of S. lycopersicum with S. habrochaites var. glabatrum 'PI-134417' followed by backcrosses with $S$. lycopersicum. The hybrids Débora Max and Bravo were utilized as commercial controls. They have low levels of the aforementioned allelochemicals. All allelochemical-rich lines tested were previously found to be resistant to one or more of the whitefly Bemisia spp., South American tomato pinworm Tuta absoluta, spider mites Tetranychus spp., or aphid Myzus persicae pests (AZEVEDO et al., 2003; GONÇALVES NETO et al., 2010; MALUF et al., 2010; OLIVEIRA et al., 2012; NEIVA et al., 2013; SILVA et al., 2013). 


\section{Rearing of the L. trifolii}

Leaves infested with $L$. trifolii larvae were collected from fieldgrown tomato plants at the HortiAgro Sementes S.A. experiment station (Ijaci, MG, Brazil, latitude 2110'S, longitude $44^{\circ} 55^{\prime} \mathrm{W}$, altitude $805 \mathrm{~m}$ ), in order to establish a mass rearing in the laboratory, according to the methodology proposed by ARAÚJO et al. (2007), with modifications.

Adult insects were maintained at a room temperature of $25.0 \pm 1.0^{\circ} \mathrm{C}$, a relative humidity of $75 \pm 10 \%$ and a $12 \mathrm{~h}$ photophase. They remained in acrylic cages $(1.0 \times 1.0 \times 0.6 \mathrm{~m})$ with orifices of $0.3 \mathrm{~m}$ in diameter and with their sides covered with voile fabric for air circulation. Petri dishes $5 \mathrm{~cm}$ in diameter with dental cotton balls soaked in a $10 \%$ v:v honey solution were placed within the cages to feed the adult insects. Each cage received about five 55 day-old tomato plants of 'Santa Clara', a standard cultivar with a known pattern of susceptibility to pest insects. The plants remained in the cages for 48 hours, for infestation, and after this period, the plants were left for four days on a bench in a climate controlled room (temperature $25 \pm 2{ }^{\circ} \mathrm{C}$, relative humidity of $70 \% \pm 10 \%$ and $12 \mathrm{~h}$ photophase) until the insects completed their larval development. Subsequently, the mined leaves were detached, and their petioles were immersed into glass tubes $6 \mathrm{~cm}$ in length $\times 1.6 \mathrm{~cm}$ in diameter filled with water. The glass tubes containing the leaves were placed in $26 \times 40 \mathrm{~cm}$ trays, so that the larvae could exit the leaves and pupate on the trays. The pupae were collected, placed in Petri dishes of $10 \mathrm{~cm}$ in diameter and enclosed in PVC film perforated with an entomological pin, where they were kept until their emergence as adults.

\section{Test of resistance to $L$. trifolii}

The tomato genotypes were seeded in a plastic greenhouse and were put into 128-cell expanded polystyrene trays prefilled with the commercial substrate Tropstrato $\mathrm{HA}^{\odot}$. Eighteen days after emergence, the seedlings were transplanted into $2 \mathrm{~L}$ polyethylene pots filled with a substrate ( 3 parts soil: 1 part dried cattle manure).
In a Phytotron-type climate-controlled room (temperature $25 \pm 2{ }^{\circ} \mathrm{C}$, relative humidity of $70 \% \pm 10 \%$, and $12 \mathrm{~h}$ photophase), plants in individual pots were arranged on benches in a completely randomized design, with nine pots for each of the eight tomato genotypes. Thirty days after the seedling transplanting, 1,600 adults of the leafminer $L$. trifolii obtained from maintenance rearing were released into the interior of the climate-controlled room. Twenty-four hours after the release, the plants were taken to a greenhouse, and after 7 days they were scored for leafminer damage. The percentage of leaves and leaflets with punctures were recorded, as were the total number of mines through all the leaflets. In order to count the number of pupae produced, leaves from each plant were removed, placed into plastic bags filled with air, and taken to the laboratory. The total number of pupae per plant was counted five days later.

\section{Statistical analysis}

Prior to the variance analysis, the data were transformed into $\sqrt{X+0.5}$. Means were compared using the Scott-Knott test $(\mathrm{p} \leq 0.05)$, with the aid of the statistical software Sisvar (FERREIRA, 2011).

\section{RESULTS AND DISCUSSION}

\section{Plant responses}

No significant differences were observed among the genotypes with regard to the percentage of leaves attacked (Table 1). However, there was a lower number of mines (Table 2) and a smaller percentage of leaflets attacked (Table 1) for the genotypes with high contents of acylsugars, when compared to the other genotypes. These results indicate that the acylsugars present in the tomato plant genotypes are associated with a non-preference for oviposition and/or feeding of adult leafminer flies.

Table 1. Mean ( \pm standard error) of the proportion of leaves and leaflets of different tomato plant genotypes with contrasting contents of allelochemicals, attacked by L. trifolii.

\begin{tabular}{lcc} 
Genotype & \% Leaves attacked & \% Leaflets attacked \\
\hline Débora Max & $61.2 \pm 5.7 \mathrm{a}$ & $23.3 \pm 2.8 \mathrm{a}$ \\
\hline Bravo & $43.9 \pm 4.7 \mathrm{a}$ & $19.1 \pm 3.2 \mathrm{a}$ \\
\hline TOM-687 & $47.0 \pm 3.5 \mathrm{a}$ & $13.9 \pm 2.2 \mathrm{~b}$ \\
\hline TOM-688 & $39.2 \pm 4.9 \mathrm{a}$ & $12.2 \pm 3.3 \mathrm{~b}$ \\
\hline ZGB-703 & $48.9 \pm 5.1 \mathrm{a}$ & $19.8 \pm 2.9 \mathrm{a}$ \\
\hline ZGB-704 & $49.9 \pm 6.3 \mathrm{a}$ & $20.3 \pm 3.7 \mathrm{a}$ \\
\hline BPX-365G-899-07-04-02 & $54.1 \pm 3.2 \mathrm{a}$ & $22.5 \pm 3.9 \mathrm{a}$ \\
\hline BPX-367E-238-02 & $60.1 \pm 6.5 \mathrm{a}$ & $28.3 \pm 3.2 \mathrm{a}$ \\
\hline
\end{tabular}

Means followed by the same letter do not differ statistically from each other by the Scott \& Knott test $(p \leq 0.05)$. 
The concentrations of zingiberene and 2-tridecanone in the tomato lines tested in this study were ineffective in demonstrating non-preference for feeding and/or oviposition of L. trifolii adults, in contrast to what occurred in the genotypes with high acylsugar contents. The responses of the zingiberene or 2-tridecanone rich lines to L. trifolii contrasts with the responses obtained against other pest arthropods. For example, when tested for resistance to the South American tomato pinworm Tuta absoluta, the whitefly Bemisia spp., and mites from the Tetranychus genus, the levels of the allelochemicals zingiberene and 2-tridecanone in these high-allelochemical lines were effective at promoting higher resistance levels (GONÇALVES NETO et al., 2010; MALUF et al., 2007; OLIVEIRA et al., 2012; NEIVA et al., 2013).

Similar to the findings of the present study, HAWTHORNE et al. (1992) demonstrated that the wild accession S. pennellii 'LA-716' (which has a high acylsugar content) as well its $\mathrm{F}_{1}$ hybrid with a cultivated tomato, were less preferred by leafminer adults for feeding and/ or oviposition, when compared with the commercial control treatment. This was verified by evaluating the number of punctures and the density of the mines per leaf in the plants. The resistance level of the wild accession variety was greater than that of the $F_{1}$ hybrid.

ERB et al. (1993) evaluated the resistance to L. trifolii among $F_{1}$ hybrids that were obtained through interspecific crosses between the domesticated tomato $S$. lycopersicum and the following wild species: S. pennellii; S. habrochaites var. glabratum, S. habrochaites var. typicum; S. cheesmani; S. chilense; S. pimpinellifolium and S. lycopersicum var. cerasiforme. The authors pointed out that all of the hybrids were resistant to the leafminer fly. Nevertheless, the hybrids S. lycopersicum $\mathrm{x} S$. pennellii, i.e., those that possess high contents of acylsugars, presented a higher level of resistance to the pest than the other hybrids.

AZEVEDO et al. (2003), in a study with the South American tomato pinworm Tuta absoluta, compared the resistance level of genotypes of a tomato plant with a high zingiberene content (selected from an $\mathrm{F}_{2}$ population from the cross
S. habrochaites var. hirsutum 'PI-127826' $\times$ S. lycopersicum 'TOM-556') with the wild species $S$. habrochaites var. hirsutum 'PI-127826' and S. pennellii 'LA-716'. Like L. trifolii, T. absoluta makes mines in plant leaves during its larval phase. All of these genotypes were more resistant than the commercial control, which has low allelochemical content. However, the species $S$. pennellii, which has a high acylsugar content, presented the highest levels of resistance to T. absoluta.

Out of the 42 tomato plant subsamples evaluated for resistance to $L$. trifolii through the mechanism of antixenosis or non-preference, 2 were found to be more resistant than the cultivar 'Santa Clara', as indicated by the number of L. trifolii mines. The resistance was significantly correlated with the low density of the trichomes and with the presence of hydrocarbons (C9 to C30) in the plant leaves (FERNANDES et al., 2012).

The percentage of leaves attacked was greater than that of leaflets attacked (Table 1), indicating that $L$. trifolii does not attack plants in an aggregative pattern, but rather in a randomly distributed manner. Similar results were obtained by MOREIRA et al. (1999) when evaluating the attack behavior of $L$. trifolii in an $\mathrm{F}_{2}$ tomato plant population derived from the cross of $S$. habrochaites var. glabratum $\times$ S. lycopersicum (which is presumably rich in methyl-ketone allelochemicals).

\section{Effects on insect biology}

The genotypes Débora Max ( $55.0 \pm 6.6$ pupae/plant) and Bravo (36.2 \pm 5.6 pupae/plant), which are both considered susceptible to $L$. trifolii, presented the highest number of pupae (Table 2). The other genotypes did not differ from Bravo, the control treatment with the lowest number of pupae, with the exception of the two lines with high acylsugar content ('TOM-687' and 'TOM-688') and one of the lines with a high 2-tridecanone controls ('BPX-365G-899-07-04-02'), which presented fewer pupae than both the commercial checks (Table 2).

The number of pupae per plant showed that, in all of the genotypes, the insect was able to develop through its larval

Table 2. Mean ( \pm standard error) of the number of pupae and mines/plant produced by L. trifolii in different tomato plant genotypes with contrasting contents of allelochemicals in their leaves.

\begin{tabular}{lcc} 
Genotype & $\mathbf{N}^{\circ}$ Pupae & $\mathbf{N}^{\circ}$ Mines \\
\hline Débora Max & $55.0 \pm 6.6 \mathrm{a}$ & $31.3 \pm 3.5 \mathrm{a}$ \\
\hline Bravo & $36.2 \pm 5.6 \mathrm{~b}$ & $19.2 \pm 4.4 \mathrm{a}$ \\
\hline TOM-687 & $21.5 \pm 3.6 \mathrm{c}$ & $12.3 \pm 1.7 \mathrm{~b}$ \\
\hline TOM-688 & $15.6 \pm 3.5 \mathrm{c}$ & $10.2 \pm 2.2 \mathrm{~b}$ \\
\hline ZGB-703 & $31.1 \pm 5.5 \mathrm{~b}$ & $22.0 \pm 4.3 \mathrm{a}$ \\
\hline ZGB-704 & $30.7 \pm 5.1 \mathrm{~b}$ & $21.8 \pm 5.4 \mathrm{a}$ \\
\hline BPX-365G-899-07-04-02 & $16.5 \pm 3.3 \mathrm{c}$ & $18.8 \pm 4.2 \mathrm{a}$ \\
\hline BPX-367E-238-02 & $36.5 \pm 9.7 \mathrm{~b}$ & $28.0 \pm 7.1 \mathrm{a}$
\end{tabular}

Means followed by the same letter do not differ statistically from each other by the Scott \& Knott test $(p \leq 0.05)$. 
stage and become a pupa. In a resistant plant, it is expected that there will be a decrease or even a suppression of pupal production (when compared to a susceptible plant), or that pupae should weigh less and be smaller. These effects would indicate a mechanism of antibiosis, caused by the secondary metabolites (STOUT; WORKMAN; DUFFEY, 1994) ingested by the insect, and that cause negative effects on their development. The wild tomato plant species (S. pennellii, S. habrochaites var. hirsutum, S. habrochaites var. glabratum) that gave rise to the genotypes tested in the present work are known to possess trichomes that secrete allelochemicals (acylsugars, sesquiterpenes, methyl-ketones), which are reportedly associated with resistance to many pest arthropods (FREITAS et al., 2000; GONÇALVES et al., 1998; RESENDE et al., 2002). However, the leafminer fly $L$. trifolii in the larval stage feeds on the interior of the epidermal layers of the leaf and, for this reason, the secretion of trichomes does not exert influence on the larvae, but rather on the adults, which can display nonpreference for oviposition and/or feeding.

MOREIRA et al. (1999) observed a large variation in the number of pupae produced by L. trifolii upon evaluating the resistance level of an $\mathrm{F}_{2}$ population resulting from a cross between a commercial tomato cultivar and the 2-tridecanonerich species $S$. habrochaites var. glabratum. The genotypes with a higher concentration of 2-tridecanone presented fewer pupae than the commercial tomato cultivar that had low contents of this allelochemical. This result supports those obtained in the present work for line BPX-365G-899-07-04-02.

The discrepancy in the results on the resistance levels of the two lines that are presumably rich in 2-tridecanone can be accounted for by the mechanism of oligo- or polygenic inheritance of the trait in question (MALUF et al., 2007). This can explain the existence of lines with different levels of this allelochemical. Although higher 2-tridecanone contents may occur in both lines (BPX-365G-899-07-04-02 and BPX367E-238-02), BPX-365G-899-07-04-02's greater level of resistance to $L$. trifolii may reflect its higher 2-tridecanone level relative to 'BPX-367E-238-02'.

The results of the present study demonstrate that genotypes that are rich in acylsugars ('TOM-688 and 'TOM-687) are resistant to $L$. trifolii both through the mechanism of antixenosis (there was a lower number of mines per plant and a lower percentage of leaflets attacked) and by virtue of the antibiosis mechanism (there was a smaller number of pupae). However, in the 2-tridecanone rich line 'BPX-365G-899-07-04-02', the antibiosis mechanism (in which there was a lower number of pupae) was predominant.

\section{CONCLUSION}

The genotypes 'TOM-687' and 'TOM-688', with a high acyl sugar content, and 'BPX-365G-899-07-04-02', with a high content of 2-tridecanone, show resistance to $L$. trifolii.

\section{ACKNOWLEDGMENTS}

The authors are grateful to FAPEMIG, CNPq, CAPES, and HortiAgro Sementes S.A., for their financial support.

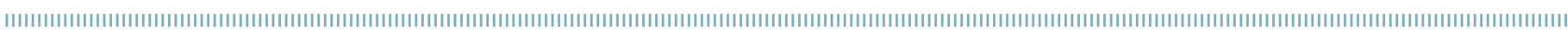
REFERENCES

ARAÚJO, E.L.; PINHEIRO, S.A.M.; GEREMIAS, L.D.; MENEZES NETTO, A.C.; MACEDO, L.P.M. Técnica de criação da mosca minadora Liriomyza trifolii (Burgess) (Diptera: Agromyzidae). Campo Digital, Campo Mourão, v.2, n. 1, p.22-26, 2007.

AZEVEDO, S.M.; FARIA, M.V.; MALUF, W.R.; OLIVEIRA, A.C.B.; FREITAS, J.A. Zingiberene-mediated resistance to the South American tomato pinworm derived from Lycopersicum hirsutum var. hirsutum. Euphytica, Wageningen, v.134, n.3, p.347-351, 2003.

CARVALHO, J.R.; PRATISSOLI, D.; PAES, J.P.P.; ZUIM, V.; STINGUEL, P.; SALOMÃO, K.P.O.S.; MINAS, R.S. Seletividade de fungicidas utilizados na cultura do tomateiro (Lycopersicum esculentum, Mill.) a Trichogramma pretiosum. Nucleus, Ituverava, v.9, 2012.
ERB, W.A.; LINDQUIST, R.H.; FLICKINGER, N.J.; CASEY, M.L. Resistance of selected interspecific Lycopersicum hybrids to Liriomyza trifolii (Diptera: Agromyzidae). Journal of Economic Entomology, Maryland, v.86, n.1, p.100-109, 1993.

FERNANDES, M.E.; FERNANDES, F.L.; SILVA, D.J.H.; PICANÇO, M.C.; JHAMC, G.N.; CARNEIRO, P.C.; QUEIROZ, R.B. Trichomes and hydrocarbons associated with the tomato plant antixenosis to leafminer. Anais da Academia Brasileira de Ciências, Rio de Janeiro, v.84, n.1, p.1678-2690, 2012.

FERREIRA, D.F. Sisvar: a computer statistical analysis system. Ciência e Agrotecnologia, Lavras, v.35, p.1039-1042, 2011. 
FREITAS, J.A.; MALUF, W.R.; CARDOSO, M.G.; GOMES, L.A.A.; BEARZOTTI, E. Inheritance of foliar zingiberene contents and their relationship to trichome densities and whitefly resistance in tomatoes. Euphytica, Wageningen, v.127, n.2, p.275-287, 2002.

FORNAZIER, M.J.; PRATISSOLI, D.; MARTINS, D.S. Principais pragas da cultura do tomateiro estaqueado na região de montanhas do Espírito Santo. Vitória: Incaper, 2010. p.185-226.

FREITAS, J.A.; MALUF, W.R.; CARDOSO, M. das G.; BENITIES, F.R.G. Métodos para a quantificação do zingibereno em tomateiro, visando à seleção indireta de plantas resistentes a artrópodes-praga. Acta Scientiarum, Maringá, v.22, n.4, p.943-949, 2000.

GALLO, D.; NAKANO, O.; SILVEIRA NETO, S.; CARVALHO, R.P.L.; BAPTISTA, G.C.; BERTI FILHO, E.; PARRA, J.R.P.; ZUCCHI, R.A.; ALVES, S.B.; VENDRAMIM, J.D.; MARCHINI, L.C.; LOPES, J, R.S.; OMOTO, C. Entomologia Agrícola. 3. ed. Piracicaba: Livroceres, 2002. 920p.

GONÇALVES, M.I.F.; MALUF, W.R.; GOMES, L.A.A.; BARBOSA, L.V. Variation of 2-tridecanone level in tomato plant leaflets and resistance to two mite species (Tetranychus sp.). Euphytica, Wageningen, v.104, n.1, p.33-38, 1998.

GONÇALVES NETO, A.C.; SILVA, V.F.; MALUF, W.R.; MACIEL, G.M.; NÍZIO, D.A.C.; GOMES, L.A.A.; AZEVEDO, S.M. Resistência à traça-do-tomateiro em plantas com altos teores de acilaçúcares nas folhas. Horticultura Brasileira, Brasília, v.28, n.2, p.203208, 2010.

HAWTHORNE, D.J.; SHAPIRO, J.A.; TINGEY, W.M.; MUTSCHER, M.A. Thichome-borne and artificially apllied acylsugars of wild tomato deter feeding an oviposition of the leafminer Liriomyza trifolii. Entomologia Experimentalis et Applicata, v.65, n. 1, p.6573, 1992.

MALUF, W.R.; CAMPOS, G.A.; CARDOSO, M.G. Relationships between trichome types and spider mite (Tetranychus evansi) repellence in tomatoes with respect to foliar zingiberene contents. Euphytica, Wageningen, v.121, n.1, p.73-80, 2001.

MALUF, W.R.; INOUE, I.F.; FERREIRA, R.P.D.; GOMES, L.A.A.; CASTRO, E.M.; CARDOSO, M.G. Higher glandular trichome density in tomato leaflets and repellence to spider mites. Pesquisa Agropecuária Brasileira, Brasília, v.42, n.9, p.1227-1235, 2007.
MALUF, W.R.; SILVA, V.F.; CARDOSO, M.G.; GOMES, L.A.A.; GONÇALVES NETO, A.C.; MACIEL, G.M.; NÍZIO, D.A.C. Resistance to the South American tomato pinworm Tuta absoluta in high acylsugar and/or high zingiberene tomato genotypes. Euphytica, Wageningen, v.176, n.1, p.113-123, 2010.

MOREIRA, L.A.; MOLLEMA, C.; HEUSDEN, S.V. Search for molecular markers to Liriomyza trifolii resistance in tomato. Euphytica, Wageningen, v.109, n.3, p.149-156, 1999.

NEIVA, I.P.; ANDRADE JUNIOR, V.C.; MALUF, W.R.; OLIVEIRA, C.M.; MACIEL, G.M. Role of allelochemicals and trichome density in the resistance of tomato to whitefly. Ciência e Agrotecnologia, Lavras, v.37, p.61-67, 2013.

OLIVEIRA, C.M.; ANDRADE JUNIOR, V.C.; MALUF, W.R.; NEIVA, I.P.; MACIEL, G.M. Resistance of tomato strains to the moth Tuta absoluta imparted by allelochemicals and trichome density. Ciência e Agrotecnologia, Lavras, v.36, p.45-52, 2012.

RESENDE, J.T.V.; CARDOSO, M.G.; MALUF, W.R.; SANTOS, C.D.; GONÇALVES, L.D.; RESENDE, L.V.; NAVES, F.O. Método colorimétrico para quantificação de acilaçúcar em genótipos de tomateiro. Ciência e Agrotecnologia, Lavras, v.26, n.6, p. 1204-1208, 2002.

RESENDE, J.T.V.; MALUF, W.R.; CARDOSO, M.G.; GONÇALVES, L.D.; FARIA, M.V.; NASCIMENTO, I.R. Resistance of tomato genotypes to the silverleaf whitefly mediated by acylsugars. Horticultura Brasileira, Brasília, v.27, n.3, p.345-348, 2009.

RESENDE, J.T.V.; MALUF, W.R.; FARIA, M.V.; PFANN, A.Z.; NASCIMENTO, I.R. Acylsugars in tomato leaflets confer resistance to the South American tomato pinworm, Tuta absoluta Meyr. Scientia Agricola, Piracicaba, v.63, p.20-25, n. 1, 2006.

SILVA, A.A.; MALUF, W.R.; MORAES, J.C.; ALVARENGA, R.; COSTA, E.M.R. Resistência a Myzus persicae em genótipos de tomateiro com altos teores foliares de aleloquímicos. Bragantia, Campinas, v.72, n.2, p.173-179, 2013

SILVA, V.F.; MALUF, W.R.; CARDOSO, M.G.; GONÇALVES NETO, A.C.; MACIEL, G.M.; NÍZIO, D.A.C.; SILVA, V.A. Resistência mediada por aleloquímicos de genótipos de tomateiro à mosca-branca $\mathrm{e}$ ao ácaro-rajado. Pesquisa Agropecuária Brasileira, Brasília, v.44, n.9, p.1262-1269, 2009.

STOUT, M.J.; WORKMAN, J.; DUFFEY, S.S. Differential induction of tomato foliar proteins by arthropod herbivores. Journal of Chemical Ecology, New York, v.20, n.10, p.2575-2594, 1994. 